\title{
FORM AND ESSENCE AS COGNITIVE PRIORITIES OF MUSICOLOGICAL SCIENTIFIC DISCOURSE
}

\section{Samoilenko A. I.}

\section{INTRODUCTION}

In the context of musicological discourse (musicological understanding and interpretation), the concept of form takes on different semantic projections, thereby indicating the multilevel meaning of form in music. In the most general cognitive, objective and subject musicological conceptual presentation, the form is the form of music life in culture; the form of music itself is its linguistic nature, compositional and typological properties; the form of influence and perception (acceptance - awareness). In all three positions, this concept is due to the specifics of the expressive artistic music nature, both its symbolic properties and special semantic connections with the real world, as well as the ability to produce its own special meanings. If, in its ability to generate its own semantic world, music is in solidarity with other types of art, then in terms of the quality of subject-semantic content it is noticeably different both from them and from other spheres of cultural semantic activity.

The meanings expressed by music are specific only for it; they are unique both in artistic and in general life ontological purpose, as they reproduce (create) the highest and deepest levels of human existence. The possibility of their musical production is explained by the principles of the musical form as a semiological phenomenon - as a specialized language sphere, which is generated by the universal human need for a personal aesthetic completeness of experiencing the life meaning (being).

The idea of form in its possible musicological presentation, of course, if we free it from narrowing technological approaches, moves from a more general cultural, historical and life context to the field of constructing a musical text and understanding music as a text, then to the organization of the conditional semantic space of music, its intext - a set of specific musical artistic intentions.

Thus, the movement of musicological thought arises from the external formal organization of musical art, the musical and creative process to its immanent laws, to the internal "speech" of music as its internal form, which is the key psychosemantic factor of musical influence.

We admit a stronger statement that the question of the internal form, as well as this phenomenon itself, is connected with the main psychosemiotic law of music; knowledge of this law, discussion of its sides and terms makes it 
possible to clarify the "difficult problems" of consciousness, which are faced today by representatives of not only the humanities, but also the natural sciences. An art history methodology that attracts semiological approaches can contribute to the solution of some complex issues in the voluminous sphere of human science, including also the connection with the study of cognitive processes and methods for their modeling.

The prerequisite for this is the special unity of form and meaning that the semiological organization of musical art reveals, in particular the relationship between form and essence of meaning in music, which is provided by the phenomenon of internal form.

It should be emphasized that the question of the essence of art is in solidarity with the question of the main law of human self-consciousness: of humanity as the "assemblage point" of a person as a thinking and feeling being, understanding and speaking one, that is, expressing his thoughts and feelings in the system of utterances, with the help of language. In the end, this question gains a wide noetic resonance, referring to the idea of the spirit, instilling in the human individuality; it also leads to psychological deepening in connection with the study of human consciousness modalities as ideally virtual substances that ensure the continuity and dynamics of musical thinking.

Consequently, the idea of an internal form, as a central place and the law of the musical logo, leads to the need for the category of "internal man", indicating not only the structure of musical thinking and the development of the musical "way of thinking", but the essence of music as its unique semantic vocation.

As analytical prolegomena of the proposed concept of semiological interaction of musicological thought with the formative and semantic principles of music, we note the following four stages in the formation of musical thought: material and physical, sound-organizational, phonemesonoristic; suggestive and empathic, communicative (connecting), intonational and speech; structurally isolating, compositionally interpreting; understanding, generalizing, abstracting and conceptualizing.

Among these, the first characterizes the material nature of the musical language, its matter and perceptual purpose; the first and second in their unity become the platform for the emergence of genre properties (structures) of music; the second and third represent the conditions for musical composition and style formation, that is, a single compositional textual field of music; the fourth allows to isolate the stylistic content of the music, it is responsible for all processes of semantic representation.

It is this final and generalizing level of music formation and impact that becomes the basis for a musicological discourse, which enters into a dialogue with musical thought, with the language of music. 


\section{From musical concepts to the metalanguage of musicology}

Once again, we note that form and essence are equivalent to a pair of concepts of form and meaning, since the essence always forms the semantic phenomenon centers in which the essential principle can be detected; these are always those two poles that cannot be dispensed with in any semiological musicological analysis. However, the concept of form in recent years (the beginning of the XXI century) has lost not only its scientific attractiveness, but also its explainability, since the approach to the process of form-creation and, most importantly, to forms of musical thinking, musical consciousness, as well as to forms of personal consciousness in general, have come under dictate of a phenomenological approach.

Phenomenology in its basic philosophical form, as well as phenomenology that has grown on the basis of hermeneutics, remains today that area of knowledge that leaves more questions than answers. Being in most cases an author's (that is, individualized-subjective, including discursive) discipline, it introduces relevant and promising terminology (associated, in general, with the concepts of noema, noesa, noetic analysis), but does not offer support on objective reality, on a specific historical person.

The problem is that phenomenology does not rely on a sufficiently clear definition of the human personality and human consciousness structure. Meanwhile, when we sequentially consider a dichotomous pair of form and essence, we are convinced that their connecting link, through which both of these phenomena are best revealed, is the internal form. And although G. Shpet ${ }^{1}$, partially addressed the problem of the internal form, he did not make serious analytical support for this concept. Since the concept of an internal form needs to be clarified (the internal form of what?), this definition expands to the following definition: "Internal form of thinking" or "internal form of consciousness", which clarifies, but also significantly expands the research approach.

The duality of the internal form of thinking as an object of both music and musicology was stated in one of the last works by I. Kotlyarevskyi, who, in particular, wrote: "Understanding the multiplicity of linguistic means even within the same sphere of mental activity requires setting an exciting research problem - the development of thinking in the field of musical art in the light of the communication media system evolution. < ..> At the present stage, it seems possible to single out one aspect in it - the evolution of thinking in the musical and artistic sphere and the reflection of this evolution in two language systems: means of musical expressiveness and the terminological apparatus of musicology"2.

\footnotetext{
${ }^{1}$ Шпет Г. Внутренняя форма слова. Этюды и вариации на темы Гумбольта. М., 2006.

${ }^{2}$ Котляревский И. К вопросу о понятийности музыкального мышления. Музыкальное мышление: сущность, категории, аспекты исследования. К.: Музична Україна. С. 28.
} 
I. Kotlyarevskyi posed the problem of forms of musical thinking in connection with the categorical system of musicology. He emphasized that the forms of thinking by music and in music should be presented in an appropriate conceptual system, including verbal musicological explications based on the nature and properties of music itself. "Musical and artistic categorical system", "movement of the means of musical expressiveness" to "shaping their content side as forms of musical thinking" - these are the subjects the study of which I. A. Kotlyarevskyi called "one of the most important methodological problems" of musicology ${ }^{3}$. He considered the premise of this study, first of all and most of all, as the need to overcome the habit of substituting the conceptual nature of one of its forms - verbal, that is, to overcome the habit of narrowing the functions of a concept as a form of thinking - as an expression of the consciousness logical possibilities.

This methodological idea presented in one of the last works of I. A. Kotlyarevskyi, still remains only outlined; meanwhile, it is associated with key questions for modern musicology about the nature and essence of musical consciousness - to the extent that consciousness can be called musical, that is, capable of generating a logical system of music.

Continuing, trying to develop the position of I. Kotlyarevskyi, we will answer the following question: is it enough for the consciousness of one language, even if it is such a universally recognized and difficult-to-use as verbal? Already the variety of subject orientations of the word, among which the focus on "inexpressible" and "hidden", on "concealment" (G. Gadamer ${ }^{4}$ ), which contributes to an increase in suggestiveness, rhetoric, allegory and so on, indicates the limited form of verbal and linguistic expression, which the word is somehow trying to overcome.

Consequently, the difficulty of understanding with the help of the word is explained by the fact that understanding needs the "language of the inexpressible", indescribable - the "musicality", the concept of which becomes synonymous with the concept of understanding completeness in the poetics of L. Vygotskyi: consciousness "does not speak" in one, but in many languages with us.

Musical thinking is derived from "emotional thinking" (the term of L. Vygotskyi) and is related to any work of thought, to the work of consciousness as a whole. It represents the meaning-generating work of meanings that determines the nature and characteristics of "musical concepts" - concepts that are expressed, formulated in a musical way. The importance of these concepts is revealed in the following words: "The fact that I think things outside of me does not change anything in them. And the fact that

\footnotetext{
${ }^{3}$ Котляревский И. К вопросу о понятийности музыкального мышления. Музыкальное мышление: сущность, категории, аспекты исследования. К.: Музична Україна. С. 33-34; 28.

${ }^{4}$ Гадамер Х.- Г. Актуальность прекрасного: Пер. с нем. М.: Искусство, 1991.
} 
I think of affects, that I put them in a different attitude to my intellect and other instances, changes a lot in my mental life. Simply speaking, our affects act in a complex system with our concepts..." 5 .

Due to the connection with "emotional thinking", the conceptual structures of music appear as "communicating meanings" according to the "pattern: person - person, person - thing - person", but not "person - thing", that means, they have a communicative and dialogical nature. From here there is their function of generalization as indirect communication, generating a double functional orientation of the sign (communication - generalization, generalization - mediated communication). L. Vygotskyi deduces the main "law" of concepts as "semic units" - supporting forms of meaning formation and meaning-forming activity of consciousness: what is the form of communication, such is the generalization. Thus, it allows one to find the path of musical semantics - musical meanings generated by "emotional thinking” as a transition from the real conditions of musical creativity (performing genre forms) to the conventionality of compositional decisions. In a musical text, one can find the correlation of the levels of musical meanings generalization, that is, the correlation of the levels of concepts. And these levels represent a stylistic and stylistic consequence of communicative genre forms of music separation (forms of communication by music).

The above-mentioned also allows us to find certain sets of meanings in the phenomenon of musical consciousness (awareness) - both stable and moving semantic conglomerates of musical and linguistic entities, which enter both within themselves and in relation to each other into complex relations of equivalence and transitivity that organize the transfer of meaning and the conceptual nature of such a transfer.

Of course, we will not dispute the fact that the word remains the central (centralizing) principle of cultural communication: in reality, in the life of culture, in culture as a memory, it is precisely those meanings that are stipulated, "spoken out" in the word, and receive a verbal form. The word of music also becomes an indispensable companion of musical meaning - or rather, semantic meaning in music, the presence of which is caused by the human need to comprehend - create and understand meanings, because in itself "... the meaning is in music, if it is, then it does not need us" ${ }^{6}$. However, it should immediately be noted that until today the well-known definitions of meaning (musical meaning) and semantics (artistic, specifically musical) are preliminary; only recently, these concepts have begun to claim their own categorical status (largely thanks to related humanitarian disciplines aesthetics, psychology, cultural studies). Based on the idea of meaning as a

${ }^{5}$ Выготский Л. О психологических системах. Л.С. Выготский. Собр. соч. в 6-ти mомах. Т.1. М.: Педагогика, 1982. С. 126.

${ }^{6}$ Гессе Г. Игра в бисер . М.: Художественная литература, 1969. С. 135. 
certain stable integrating (correlation, connection, paradigm) of all value definitions of a person in culture, we note that musical semantics is most often considered as "echoes" of general semantic quantities, which significantly narrows it.

The complexly mediated relations between a phenomenon and its conceptual expression are especially noticeable when referring to such terms as "meaning", "logo", "symbol", "artifact", etc., which, one way or another, have to be touched (at least, imply) when studying the phenomenon of musical form - form in music, internal form as a form of thinking (consciousness). It is with the last one that the mystified - almost mystical - ability of a musical image (personified in the musical art of meaning) is associated with becoming an objective reality of culture, not being a material reality in the direct and full meaning of these words.

The experience of literature as a whole is expressed in the formula "word about word, addressed to the word" ${ }^{7}$; such is the experience of all humanitarian knowledge. The latter looks for a thought that "speaks out" in a word, seeks an adequate verbal form for "its" semantic intentions. However, with the same right, we can use the formula "music about music turned to music" - and as a conceptual basis of musical self-reflection (self-expansion of the musical logo) to identify noetic categories ${ }^{8}$ and derivatives of them.

As G.-F. Leibniz noted, “... the best way the mind works is that it can discover few thoughts from which an infinite number of other thoughts flow in order, just as from several numbers ... you can deduce in order all the others... Since there are infinitely many concepts that comprehended, it is also possible that the concepts, comprehensible of thems, were few ...»

Musical concepts, comprehensible of them, suggest finding the boundary between the conditional and the unconditional in music, which is extremely difficult. The path to the musical content (semantic content of music) is most justified to begin in the direction opposite to the musical influence - from the already conceptually defined, confirmed by the genre and style historical practice of the music of the parties, from the steady experience of endowing music with "names", from the conventionally symbolic aspects of musical perception (interpretation of music) ${ }^{9}$.

The identification of musical semantics is the result of a semantic representation of music, which appears to be an abstraction of musical meanings from sound, creating in this way a new psychological reality for the

${ }^{7}$ Бахтин М. Проблемы поэтики Достоевского. М.: Художественная литература, 1972; Бахтин М. Слово в романе. М. Бахтин. Вопросы литературы и эстетики. Исследования разных лет. М.: Художественная литература, 1775. С. 72-233.

${ }^{8}$ Самойленко А. Музыковедение и методология гуманитарного знания. Проблема диалога. Одесса: Астропринт, 2002.

${ }^{9}$ Эко У. Отсутствующая структура. Введение в семиологию. СПб.: ТОО ТК «Петрополис», 1998. С. 13. 
sign-significant functions of music. Semantic representation is associated with the translation of musical meanings into a new measurement system, including conceptual and verbal-conceptual explanation and clarification of sound. The last one makes it possible to increment musical values, their programming: it is the conceptual level of consciousness that provides the opportunity to transfer past experience to previously unexplored situations, that is, the possibility of forecasting (both musical and musicological).

Thus, there arises the opportunity to discover and study musical precedents for semantic transcoding, since the latter is determined in connection with the endowment of the old "incentives" - structural formations - with new meanings and in connection with the endowment of new "incentives" with old meanings. The musicological analysis of music is aimed specifically at the coverage of the possible interactions of a given structural formula (reception of exposition) with other semantic functions and a given (known) semantic meaning with other constructions. Actually, we should talk about compositional, and as a result of it, genre and style (or rather, stylegenre), reorganization of music.

We can approach "musical concepts" as psychological artifacts - the result of material and ideational objectification of a person's relationship to the external and internal conditions of his being. A psychological artifact or artifact as a psychological phenomenon is those thoughts, feelings, sensations, perceptions, judgments, concepts about them that are significant for a person. That means, they express a symbolic arrangement of personal consciousness. They consolidate and make available for reproduction - transmission such properties of the mental activity of the subject as abilities, needs, attitudes, intentions, "views", and something else.

From them grows art content and consciousness in their interdependence; each of the named "contents" has its own "conceptual objectivity", which is correlated with the external, and is free from it. The similarity of these "contents" arises, therefore, due to the fact that art and consciousness create their own external object conditions on the basis of their own interests. This circumstance compels, firstly, to recall the rule that was discovered back in antiquity (Protagoras), who states that a person is the measure of all things; secondly, to find in the creation of a special conceptual objectivity, the intentional "structure" of a musical work, a phenomenon of the internal form of musical consciousness.

Let us once again draw attention to the fact that the problem of the internal form in musicology was not posed due to the uncertainty - the subject and terminological - of the original concept. At the same time, thanks to the research of L. Vygotskyi and his followers, one can speak of "pure meanings", which, expressing intentional strength and special needs of consciousness, guide and operate with a word, moving from thought to a verbal structure: 
they form the subject field of music. Pure meanings should be considered as those figurative meanings that exist in the mind in a holistic, spontaneous, orderly, but not verbalized, pre-verbal form. Thanks to "pure meanings" as a phenomenon of intentional consciousness, one can consider musical meanings and a musical language as a side of the internal form, as a premonition of a word and a possible internal form of a word, peculiarly overcome and rearranged in an external utterance, in an external speech.

However, in music, the inner form always remains leading. It has its own logic, not canceled by the rules of verbal speech, which is represented in exact accordance with those processes that occur in the mind or mind of a person. Music is extremely anthropological, since it arises and exists in the image and likeness of man; it is the most profound and, probably, the true measure of the inner man - the inner essential-semantic structure of mankind. Therefore, firstly, it is very difficult to explain the symbolic content of musical speech; secondly, in principle, it is impossible to "translate" the content of music into the language of verbal definitions. At the same time, it is possible to create only a parallel series of verbal categories, which, illuminating the musical content, reproducing certain contours of the internal musical form, form their own circle of meanings, which allows not only to reveal the conditional content of the composition, but also transmit musically into the space (into the consciousness) of culture musical and sense idea - the image of the "inner man" as the perfect semantic principle of being. Thus, there is no need to try to translate music into the "language of the word", but there is a need to find such a symbolic musicological word - and that way of constructing a musicological discourse that will most closely correspond to the semantic volume of musical thinking.

Here it is time to turn to what we mean by discourse and what is appropriate to understand by musicology discourse. Discursiveness for itself implies a particular use of the word. But this special speech use, which by its presence already indicates the cognitive causes and goals of human activity, creates those semantic orientations of the word among the words, thanks to which the conceptual depth is acquired.

The most essential in the concept of discourse as a special verbalspeech phenomenon is its processuality, in which the final result of verbal explication is determined by the process of the word birth, adequate to the content of thought. Not less important is the fact that the discourse always, one way or another expresses individual and personal positions, even if they are attached to some group priorities or aimed at the norms of collective consciousness.

The category of discourse is in close, partly antinomic, interaction with the phenomenon of the text. When we turn to musicological research, we focus our attention on the final results, on the structure, complete logic and 
delimitation of this experience; that means, we study, in essence, musicological thought as a complete and separate text in its construction. But when we want to extract in-depth content from the musicological structure, from the musicological text, to understand what the musicologist wanted to say with our text, we find ourselves already in an open discursive field. Consequently, we either plunge into the discursive field of musicology research, or float to the surface of the text; we comprehend either the effectiveness of the discourse, or the processuality of the text. As a matter of fact, such an antinomy is inherent not only in musicological research, not only in the development of ways of representing musicological thought, but in any verbal communication that takes on a specialized character.

In the discursive field of musicology, we find two of the most significant paradoxes. The first paradox is as follows. It would be natural to assume that music is the main subject of musicology. At the same time, music is a material into which musicological thought plunges, trying to understand its own intentionality and find its own context. Contextuality and intentionality are the obligatory methodological properties of musicological thought, which should be deepened and expanded in order to determine the boundaries of musicological knowledge. Consequently, the true subject of musicology is its own musicological word - that discursive experience, that cognitive tradition, due to which certain forms of verbal expression have acquired a scientific categorical musicological significance.

The second paradox is revealed when we ask ourselves whether a musicologist, in the field of musicology, - in the field of musicology discourse, - has words that are specific only to musicology and are not found in any other field? So, is there only musicology terminology? The answer is only negative, although taking into account the rather narrow, applied, instructive, educational sphere, which is associated, for example, with the course of harmony, some aspects of the course of musical form analysis, with the course of polyphony (although the very concept of "polyphony" is very broad), that is, when it comes to the particulars of building an already musical text. But as soon as musicology decides to become a science and enter the circle of humanitarian disciplines, the conceptual apparatus to which it refers acquires a very broad general humanitarian resonance orientation. Among the scientific categories of musicologists that musicology perceives and uses as its own concepts, the leading universals of the humanitarian and disciplinary circle are accumulating, from philosophical to psycholinguistic, from aesthetic to sociocommunicative.

In this regard, the main psychological antinomy of musicology discourse is being formed: on the one hand, a musicologist constantly doubts the legitimacy of those concepts that should reveal the true content of music and indicate its internal semantic form. On the other hand, the own symbolological 
methods of describing and representing a musical phenomenon, found in musicology discourse, and therefore, approaches to meaning, acquire value selfsufficiency, since they allow you to join the essence of the musical and creative process, as a process, birth, initiation and extraction, explication of meaning.

The psychological resources of musicology discourse are no less important than its general methodological, general humanitarian aesthetic attitudes. It is clear that the semantic content of music and sense content, the semantic instructions of musicologists are not identical and unequal, but it is through musicological attempts to make musical meanings (the internal form of music) accessible for quite a wide discussion, musicological discourse always remains the main language of musical understanding.

The central problem of musicology discourse today is the creation of a metalanguage - characteristic of all sciences at the end of the XX - the beginning of the XXI century. Initially, this problem was solved on the basis of linguistics as a search for an ideal language, and then it was modified towards the criteria of adequacy and completeness. Today, by a metalanguage in the field of the humanities (largely thanks to the theory of V. Rudnev ${ }^{10}$ ), we mean the spectrum of general categories that allows us to represent the cumulative experience of human social activity as real - possible: real in cultural life as the presence of certain artifacts in the broad sense of the word possible as the construction of new worlds, as the discovery of those creative resources of a person that are still unknown to him.

Therefore, among the key categories of musicology today the category of noological origin, associated with the theory of spirituality, cosmic mind and transcendence, entropy and negentropy processes occurring in human culture dominate. A musicological discourse acquires conceptual tools in order to reconstruct the present and possible "semantic realities" of a person, to deepen the abilities of the world sensual cognition, and imaginative personality game with senses. He also acquires his own cognitive style expressing, formalizing in verbal forms the attitudes of musical and musicological thought in their obligatory unity; therefore, we can state the connection between the metalanguage of musicology and the autonomization of musicology thinking style.

${ }^{10}$ Руднев В. Словарь культуры ХХ века. М., 1999; Руднев В. Новая модель реальности. М., 2016. 


\section{From the phenomenon of internal form to the category of the "internal man"}

Today, as never before, the desire of musicology to become a fundamental science and even replace a number of humanitarian disciplines in this respect is justified. This is possible due to the synthesis in the musicology discourse of the categories of aesthetics, the principles of literary poetics and hermeneutic approach, but most of all - due to the new importance of the category of internal form and its derivatives.

On the other hand, modern musicology seeks to open up its new applied possibilities in full accordance with the demands for applied knowledge that exist in the rapidly expanding and contradictory information field of modern science.

Musicology seeks to narrate about the spiritual, that is, to act as the science of the spirit and discover the summit manifestations (acme) of the human spirit; on the other hand, today much attention is paid to music therapy, various applied functions of musical art, and then musicology successfully becomes the science of the body, which, in fact, does not contradict the interest in the spirit. The interaction of spirit and body not only remains an existential characteristic of the human personality, but also precedes possible interpretations of the idea of the "inner man" (as we will see later).

A certain contradiction arising between the desire for generalizations, the construction of abstract conceptual constructions and the tendency for detailed analytical characteristics, corresponds to the above-mentioned functional duality of musicology. This contradiction at the same time explains this duality, and its character, the reason for its actualization by the complication of the subject area of musicological speculation and the deepening of some methodological positions.

As it was already noted, today for the musicological discourse the most integrative and essential are the problem of musical thinking and the related problem of musical consciousness. Moreover, the second problem - musical consciousness - reveals a certain neologism of this concept; we should talk about the mechanisms of human consciousness that are associated with the semantic properties of music, including methods of self-knowledge, the interaction of the unconscious and rationally logical spheres of consciousness, the collective and personal unconscious, and some other.

Today's social cataclysms testify only to one thing: the fundamental global - problem, the global problem of mankind is the problem of humanistic human consciousness development and improvement of its management tools.

In relation to the possibilities of musical reproduction of human consciousness semantic reality and the ways of its improvement, there are two interacting psychosemiological laws. The first concerns the nature and direction of the musical impact, due to the need to maintain human consciousness (also, 
the person as a whole, as a bio-social device) in a state of dynamic equilibrium homeostasis, harmonious interaction of all those psycho-emotional, cognitive and somatic structures that make up the "holistic" person.

Musical sense formation, like musical thinking, embraces a whole person, it is formed at all levels of human consciousness, it passes through all structural levels of a person. Thinking is a process that involves all, without exception, the existential resources of a person, because the main psychological law of music can be found in its ability to balance and equalize all the physical, mental, psychological resources of the human person.

The second law is symmetrical to the first, but already from the side of a specific person, therefore, from the side of that "inner person" that exists inside a socially equipped person "like a god in a stone statue ${ }^{11}$, but growing up, must be not only balanced, but also concentrated, have their own possessive coordination principles. Therefore, the second law should be called the law of attraction and coordination, ordering and structuring of thoughts, both in personal consciousness and in the process of musical thinking. All internal reorganizations, transformations, as a result of this - the formation of value attitudes, are organized by a single "attractive" thought principle - a place of semantic assembly. And there is no other way to realize one, to find a fulcrum in oneself. And there is no point of interaction with the outside world for human consciousness.

It is with the help of orientation toward the active attraction of thought and with the help of thought that such a philosophical trend as enactivism develops. It provides that thinking and consciousness, as inseparable, but also non-merged quantities, arise and develop in their directions only when the human mind, respectively, and the person himself, is in action. That means, they require activity from the human intellect and the whole human being: you need to "act in", include in the action, activate the mind, and this means the inclusion in the action and the whole personality structure, the whole, external and internal person.

Along with enactivism, the trend of connectionism is becoming relevant for the problems of the internal form of musical thinking. Like enactivism, it develops in some confrontation between phenomenology, constructivism and epistemology, introducing praxeological reconstructions into the general theory of knowledge. Enactivism and connectionism seem to be promising trends in an understanding approach, which allow applying the logic of cognition to an integral human subject, isolating the idea of structure of the "inner man", clarifying with its help not only the concept of the internal form, but also, in general, the phenomena of thinking and consciousness.

11 Эткинд Е. «Внутренний человек» и внешняя речь. Очерки психопоэтики русской литературы XVIII - XIX вв. М., 1998. 
The relevance of these trends is due to the increased role of personality factors, which we observe today in all spheres of human activity. It is not only about scientific or artistic activity; in recent years, the responsibility of each person for himself at the existential level has grown tremendously - it has become the main, decisive factor in life success.

Because today, the root problem for all scientific communities and most humanitarian research is the study of man and his nature. This problem motivates a significant increase in attention to the psychological resources of the human community, to the psychological aspects of human behavior and activity; resolving differently at different levels, she most intensified the methods of neurocybernetics and psychosemiological analysis, moreover, in their noticeable convergence and mutual enrichment. Common to these disciplinary areas is the problem of the "inner man", which can be revealed as a system of questions (and answers) about how the subject (personality) is arranged, organized and conditioned from the inside, what he owns at the central points of his consciousness, what he is able to dispose of and to how much thesaurus given to him by nature and society, as well as the noosphere of a holistic human culture he owns.

The preconditions for the formation of the concept of the "inner man" have been accumulating in musicology for a rather long time, since the personality of a musician, composer, performer, and listener is included in the subject matter of most musicology works, and there are thorough classification attempts to generalize and present in personal characteristics the personal experience of creating music. Moreover, as a humanitarian and symbolological musicology discourse involves the reproduction of the internal structure of consciousness of the musicologist himself, the presentation in the completed conceptual form of his own "inner man" as an immanent system of speculations, ratings, ways of experiencing.

For modern musicology, interest in metatheory becomes very indicative - as to that level of theoretical generalization, without losing its analytical depth and effectiveness, which allows us to represent in unity all the main aspects of musicological experience. The category of the "inner man" claims its place precisely in the theory of this type, that is, it claims not only to generalize, but also to integrate. The essential feature - a sign of the ontological importance of this category can be considered that it is combined with the concept of linguistic consciousness (and its structure). This means the internal linguistic structure of human consciousness. In this interpretative direction, it is able to acquire a broad humanitarian positive resonance, to withstand those contemporary author's concepts that proclaim an inevitable crisis, even a catastrophe, and not so much of a person's social history as his personal consciousness, semantic breakdown of consciousness. 
So, M. Arkadiev ${ }^{12}$ claims that the only possibility of freedom in life for a person is death. And the need to gain freedom is connected with the fact that a person needs to get rid of linguistic predestinations, since the linguistic presumption of consciousness is the social yoke that makes a person slow down, even if it was considered "accelerating inhibition". Arkadiev's approach is positive in that it points to the well-known problem of paradoxical dichotomy that arises between a person as a biologically natural being and a person as a socialized, cultured, that is, secondarily, artificially born.

As M. Mamardashvili ${ }^{13}$ has repeatedly written about this, a person is constantly forced to take into account the history of mankind that precedes his existence and the future history of humanity, since it determines the archetypes of his consciousness. Thanks to it, he is born not in emptiness, but in a "populated" world; acts not by itself, but because of a special attachment to humanity, in the interests of this humanity; it depends on the tasks that the history of mankind poses before him, but also contributes to their solution and further formulation. In the opinion of Mamardashvili and some other authors, it is precisely such an existential connection with humanity that explains the existence of higher social, including creative spiritual, needs for a person which is a guarantee of memorial memory - a guarantee of a kind of immortality.

However, according to M. Arkadiev, historical linguistic consciousness creates a gap for man and mankind through which it is impossible to jump over, and you can get rid of it only if you return to the pre-linguistic state of consciousness, although it is not indicated at what stage the evolution of the human personality, the dominance of this "saving" pre-linguistic state of consciousness is possible.

M. Arkadiev devotes his research to the substantiation of the belief that a person, as a species, is a "linguistic catastrophe" according to his origin, therefore he inevitably moves towards environmental disaster. The most fundamental dissonance of human consciousness (the entire internal structure of a person) is the collision of "speech consciousness" and the realm of the unconscious instinctive, which "makes a person dangerous both for him and for the environment (which is practically the same thing)". And one of the forms of "the struggle against linguistic activity and fundamental consciousness as a deharmonizing structure” becomes silence in its various ritual and religious forms ${ }^{14}$.

${ }^{12}$ Аркадьев М. Лингвистическая катастрофа. Антропология абсурда: новый стоицизм. М., 2011. URL: http://docplayer.ru/26142565-M-arkadev-lingvisticheskaya-katastrofamoskva-antropologiya-absurda-novyy-stoicizm.html.

${ }^{13}$ Мамардашвили М. Эстетика мышления. Беседы. М., 2000. Электронная публикащия: Центр гуманитарных технологий. URL: https:/gtmarket.ru/laboratory/basis/5061; Мамардашвили М. Необходимость себя. М., 1996.

${ }_{14}$ Аркадьев М. Лингвистическая катастрофа. Антропология абсурда: новый стоицизм. М., 2011. URL: http://docplayer.ru/26142565-M-arkadev-lingvisticheskaya-katastrofamoskva-antropologiya-absurda-novyy-stoicizm.html C. 17, 24. 
Two theoretical points surprise M. Arkadiev in his research essay more than others. Firstly, he does not mention music at all, although he is an outstanding musician and musicologist; he turns exclusively to the verbal language and the experience of verbal and linguistic consciousness, as if not noticing that an even more powerful and more ancient, archaic and pre-verbal (pralogic) musical consciousness exists and develops next to him. It is well known that the linguistic practice of consciousness is not limited only to verbal speech, but allows and assumes very diverse variants of speech of gesture-kinetic, musical and intonational, etc. Releasing this "saving anchor" of the musical language, Arkadiev seemed to raise the question to provoke a discussion about those musical and linguistic means and techniques that allow a person to "jump" through the phenomenon of semantic gap, through "linguistic cracks", to create such external and internal reality of consciousness that can justify anthropological paradoxes and suggest ways to overcome or productive use them.

At the same time, M. Arkadiev's approach is very indicative of the state in which humanitarian, in particular, art, thought is today. Turning to the psychological parameters by which a modern person can be modeled, putting forward some typological features of the personality structure, clarifying, differentiating them with respect to the capabilities of an individual, it does not bring these subject vectors to the identification of such identifying indicators that can simultaneously control both external reality, and internal semantic reality.

The holistic image of a "semantic", that is, "inert", person (man) is built on the intersection of precedent meanings and symbolic formations in which individual symbolic terms already have the completeness of semantic influence; that means, they are semantically integrative and transitional. This functional duality and semantic self-referentiality is clearly manifested in poetic creativity, defining it as the leading nominative and metonymic device for constructing a literary text. A convincing example of a metonymically interpreted internal form of poetic utterance is a poem by Osip Mandelshtam: "Give Tyutchev a dragonfly..." ${ }^{15}$, which served as the subject of a series of

\footnotetext{
${ }^{15}$ Дайте Тютчеву стрекозу -

Догадайтесь почему!

Веневитинову - розу.

Ну, а перстень - никому.

Баратынского подошвы

Изумили прах веков,

У него без всякой прошвы

Наволочки облаков.

А еще над нами волен

Лермонтов, мучитель наш,

И всегда одышкой болен

Фета жирный карандаш.
} 
analytical articles that reveal in this opus the mysterious ability of the poetic form to send to whole layers with the help of a single sign-word to send to the entire layers of not personally authorial, but also artistic history. So, the "ring of Venevitinov", presented to him by his beloved, is a sign of the failed tragic love of the poet and Zinaida Chomskaya, therefore he could not be given to anyone even after the death of the poet; the topic of "hard breath", especially in the dying minutes, connected Mandelstam with Tyutchev. According to E. Soshkin, "Commenting on the attribute assigned to Fet, - a pencil that has shortness of breath, $-\mathrm{O}$. Ronen noted the common motive of painful breathing of Mandelstam and Fet, indicated that A. A. Fet actually suffered from asthma, and found that in 1914 Mandelstam could see the pencil corrections of the dying Fet at his last poem "When breathing multiplies torment..."; "This motive of creative suffocation, voiced in the finale of the poem, invisibly permeates it from the beginning to the end" ${ }^{16}$.

This poem by Mandelstam, like other examples of his poetic thinking, forms its own "hermeneutical circle", its own, rather closed space of understanding, which can be entered only when you possess the necessary knowledge, factual information. Although the musical idea and aesthetic overtones are revealed and perceived directly and without much hermeneutic efforts. Therefore, even if there are certain symbols that require logical decoding, imagination and intuition facilitates semantic assessments, suggest the direction of understanding, thanks to the available nominal and emblematic metonymic series. Actually, it means that they produce new, different subject meanings and meaningful connections, recreating the wellknown reality in favor of the poetically possible. The significance of the internal poetic form of this Mandelstam poem is determined by the verbal and poetic details of subject references to each of the poets mentioned in it. At the same time, the proposed characteristics acquire a generalized meaning, they are addressed to the entire poetic world as a whole, and the author's names are mythologically peculiar.

E. Soshkin believes that the poetic riddle addressed to Lermontov's name is the most difficult. In our opinion, Lermontov's "torment" for the poets of the Mandelstam generation meant for them not less painful choice of the right path and the rivalry for the name of a genius: this choice was especially difficult for the poets of the Silver Age, since, following Pushkin and Lermontov, they sought to achieve the highest freedom of poetic art, obscured by nothing and no one. Consequently, Mandelstam seemed to equal his efforts to circumvent the era and be far ahead of his time with Lermontov's fate.

Calling this poem "a number of riddles", E. Soshkin singles out the symbolic opposition of "the dust of centuries and clouds" in connection with

\footnotetext{
${ }^{16}$ Сошкин Е. К пониманию стихотворения Мандельштама «Дайте Тютчеву стрекозу...» URL: http://textonly.ru/case/?issue=21\&article=16874.
} 
the name of Baratynskyi, creating a series of allusions to Baratynskyi's poetic texts and acquiring the significance of the central value antithesis of the bottom - the top; disappearances - natural eternity; death, decay immortality, beauty.

The cloud is an independent and important, yet insufficiently explored complex cultural and artistic symbol. Given the new technological methods of storing information, we can say that the cloud is a certain sphere of value accumulations that holds knowledge and relationships open by a person, thus holds memory, consciousness, and preserves them even when they are not directly addressed. As a symbolic form and its symbolic name, the cloud represents a psychological semantic life reserve; it is outside the basic positions of our life, as it rises higher - above what happens every day; it is protected from loss and destruction by its very height.

The concept of the cloud in a new psychosemantic context is found in Chapter VII of the last work of L. Vygotskyi "Thinking and Speech" "7; the scientist writes that words relate to meaning approximately like rain refers to a cloud, and this cloud freely and calmly sweeps through the sky, accumulates moisture in itself, and when it has accumulated enough moisture, it can burst into a rain of words. Thus, an outstanding psychologist uses the cloud metaphor to point to a special semantic thesaurus possessed by the "highest" levels of consciousness and without which neither verbalization nor any other linguistic communicative activity is possible. However, Vygotskyi further indicates that the cloud does not move independently in the sky, because it needs wind. If the cloud, as revealed by reasoning, symbolizes the emotional and sensual sphere from which verbal formulas are generated through rationalization, cognitive intellectual practice, then the wind is a motivational and volitional sphere associated with all vital cycles of a person, with his motor kinetic practice of a person, that is, with man as a physical, bodily being. It is not isolated from the physical side of the human subject; on the contrary, it even completely depends on it, although it acquires the importance of an effective factor in thinking and awareness only in the formation of psychological resources the immanent psychosemantics of consciousness.

As L. Vygotskyi poetically writes, "If we compared the thought above with an overhanging cloud, pouring a rain of words, then we would have to motivate the thought, if we continue this figurative comparison, to liken the wind, which sets the clouds in motion. A real and complete understanding of someone else's thought becomes possible only when we reveal its effective, affective and volitional background" ${ }^{\prime 18}$.

\footnotetext{
${ }^{17}$ Выготский Л. Мышление и речь: Изд. 5, испр. М.: Лабиринт, 1999.

${ }^{18}$ Ibid. C. 332.
} 
Consequently, in contrast to the approach of M. Arkadiev, the concept of L. Vygotskyi allows us to consider speech, including verbal, in its unity with thinking and consciousness, as not only positive, but elevating and introducing to integral existence factors of human formation, human history. He finds the natural forces of man in the psychology of consciousness and the internal form of the word, therefore he offers their analogies with the natural elements, as, for example, when he writes that "consciousness displays itself in the word, like the sun in a small drop of water. The word refers to consciousness, like a small world to a big one, like a living cell to an organism, like an atom to space. It is the small world of consciousness. A meaningful word is a microcosm of human consciousness"19.

In the works of L. Vygotskyi, one can find the prerequisites for determining the structure of the "inner man", in particular, indications of motivational and volitional, actional and physical, emotional, sensual and cognitive, intellectual and language levels. The category of the "inner man" is most directly represented in the studies of E. Etkind and D. Shchedrovitskyi, which today remain one of a kind, that is, the only representative phenomenon of the "inner man".

The study of Yefim Etkind "The Inner Man" and external speech. Essays on the psycho-poetics of Russian literature of the XVIII XIX centuries”20 are based on the analysis of the internal speech of literary works heroes, highlighting the features of its organization; attention is drawn to the fact that in the prose works of F. Dostoevskyi and A. Chekhov, the most positive characters speak a bit. If the literary heroes of these authors express their thoughts, they do it extremely poorly, stammer, and cannot find the appropriate words. Their verbal speech and verbal expressions cannot convey all that influx of feelings, all the richness of the internal content that they possess. Negative characters, on the contrary, are talkative and eloquent; they speak outright, rhetorically, effectively; they are verbose and love oratory.

E. Etkind very wittily remarks that not one of the positive characters created by Chekhov is able to speak out, and the character's keywords (for example, “... to Moscow, to Moscow ...”) acquire the meaning of a conventional symbol distracted from the real life position - a utopian detail. Thus, in the structure of the "inner man" verbal utterances, verbalization, although they are important, are not decisive. Moreover, the inability to adequately express oneself verbally indicates that the corresponding literary hero or character is very focused on himself, immersed in himself, cannot "swim out" of his inner world, and when he leaves it into the outer space, he feels regret; the world that is outside does not at all meet its expectations; therefore, he has no desire

${ }^{19}$ Выготский Л. Мышление и речь: Изд. 5, испр. М.: Лабиринт, 1999. С. 335.

20 Эткинд Е. «Внутренний человек» и внешняя речь. Очерки психопоэтики русской литературы XVIII - XIX вв. М., 1998. 
to enter into active verbal contacts, to create any effective external, verbal connections with the surrounding reality. Substantial pauses, distances between statements express to a greater extent the semantic positions of a literary character and the semantics of his personal consciousness than the meanings of spoken words. Therefore, the composition and dramaturgy of a number of works by F. Dostoevskyi and A. Chekhov takes on kinship with the musical according to the principles of the organization of the common logosphere.

A study by D. Shchedrovitskyi, which appeared in 2016, grew on the basis of Orthodox Christian teaching, discovering the fact that the idea of the "inner man" and the phrase "inner man" are widely used in Orthodox literature, uniting into the generally accepted theological category: "The most exalted is called the part of our spiritual essence in the New Testament" ${ }^{21}$. Analyzing the Old and New Testaments, Shchedrovitskyi calls for "understanding the composition and structure of the "inner man"", in connection with which he builds a harmonious system of levels of human selfconsciousness, isolating the attitude to the middle, as the most complex, to what is usually called the soul. A series of concepts proposed by him suggests a hierarchy: body - earth; soul - water; spirit - air; "Breath of life" - light, fire $^{22}$. These levels (plans of existence) are in constant interaction, not isolated from each other; therefore for the Orthodox understanding of the "inner man" the direction of interaction of these levels is extremely important. It is clear that this orientation concerns, first of all, the stratification, separation of the spiritual complex, the spiritual level, the emotional and sensual thesaurus into vital emotions - lower, earthly, which are necessary and characteristic for the first level, and higher; so, emotions that are attached to the body and depend on bodily processes are separated and compared, and emotions that tend to rise, ascend through the intellectual and cognitive sphere, through communion with the spirit, in this way achieve liberation in the light and familiarization with eternal being.

The approach proposed by D. Shchedrovitskyi makes it possible to understand that the types of vital, emotional and sensual, intellectual and spiritual modality. This means that the interaction of different types and plans of the life of consciousness, its dynamic manifestation in human life, take on a special role in the structure of the "inner man". The structured movement as a unit and the basis of the internal mental and psychological life of human consciousness determines, in our opinion, the main content of musical thinking. We confirm this theoretical position in the works of V. Razhnikov, who proposed the concept of emotional modalities, compiling a dictionary of

${ }^{21}$ Щедровицкий Д. Внутренний человек. Электронное издание, М., 2016. URL: http://shchedrovitskiy.ru/PDF/978-5-4212-0331-5_Vnutrenniy_chelovek.pdf. C. 5.

${ }^{22}$ Ibid. C. $20-21$. 
art emotions and dividing the entire emotional thesaurus of human consciousness into two spheres: simple vital emotions and aesthetic emotions. With respect to each aesthetic paradigm, V. Razhnikov finds up to twenty modal variations, considering modality as an accumulation of qualitative states that develop personal consciousness and contribute to the formation of groups of musical expressive techniques corresponding to each modality.

The relevance of the concept of modality to a musicological discourse is determined, firstly, by its productivity in relation to the concept of the "inner man," growing up on the basis of the phenomenon of inner form; secondly, by its ability to indicate the type and direction of movement, that is, point to those dynamic phenomena that determine the nature of human consciousness; thirdly, its correspondence to the dynamic nature of musical form and musical meaning.

Therefore, the concept of modality can be used in connection with the key characteristics of musical thinking and consciousness, as well as in connection with the category of the "inner man". Passing through the structure of the internal form in its connection with the idea of an "internal person", it allows to have a systematic approach to musical thinking.

\section{CONCLUSIONS}

Summarizing the research material in its final part, it is possible to structure the levels of the internal form in music, as the essential or as the form of musical thinking, correlating it with the structure of the "inner man" and the leading musical modalities as "places" and directions of attraction of meaning. The five main plans for musical shaping are structured according to the four main levels of their implementation.

The first plan - the plan of external socio-typological connections - is implemented as:

- relevant communication;

- empathy experience, emotional culture (emotional matrices);

- semantic prediction and language practice, speech exchange;

- idealization, conceptual distraction, entering the "memory of culture", strengthening the ecosphere of culture (noosphere). includes:

The second plan represents the structure of the "inner man" and

- physical bodily efforts, movements, psycho-somatics;

- motivational and volitional sphere, vital emotions, characteristic ambivalent emotions (differential), social emotions (secondary higher), aesthetic emotions - imaginations;

- comprehension, intellectual design, linguistic (sign-conceptual) structuring, objectification; 
- figurative and semantic abstraction (referring as to a "cloud" to a general cultural consciousness), imprinting of meaning in deep memory (unconscious).

The third plan allows to represent the levels of modeling of the "inner man" in music:

- tools, material and physical stuff, practical actions, efforts to produce sound - sound extraction;

- autonomous intonation-melos filling, creation of living sounding tissue (musical text), methods for extracting, stretching and developing sound tissue, differentiating sonoristic and timbre means, temporal and spatial volumes of sound, dynamic gradations;

- immanent logical techniques, compositional and temporal rules, isolation of musical signs and meanings, a compendium of musical concepts, interpretation by music and in music;

- the idea of music as a self-organizing semantic whole, musical and figurative broadcasting and relaying, the life of music in the consciousness of culture according to its own rules - the musical noosphere of culture, ideas about the genre and style, musical thinking.

The fourth plan allows to highlight the leading musical modalities as the direction of "attraction of thought", such as:

- sono-dynamic;

- (e)motive-characterological structural and compositional;

- systemic and logical;

- aesthetic.

The fifth plan of representation of the internal form in music involves, in accordance with the enactivism approach, the definition of levels of musical consciousness "influence", such as:

- sound and genre-organizational technological;

- suggestive and empathic, binding;

- structurally isolating, conceptualizing;

- generalizing stylistic.

The inter-level correlation of all these plans allows us to characterize the internal form of musical thinking, firstly, as the most focused on the idea of an "inner person", which, in turn, is the main vehicle of musical precedent meanings; secondly, as a sign-logos (semiological) whole, which is determined by the specifics of the musical construction of the form; thirdly, socio-typological connections, without which no one form of thinking is carried out. They find agreement with the model of the "inner man", that is, the contextual factors of musical thinking, entering the musical language, and are subordinate to the logic of musical thinking. 
In the structure of the "inner man", the final and "summit" is the fourth level, on which figurative and semantic abstraction occurs - "flight to the cloud" of semantic memory, which allows to capture the idea of music as a self-organizing semantic whole, shaping the musical noosphere of culture ensuring the life of music in culture consciousness according to its (music) own rules.

In terms of musical modalities, the systemic and logical and aesthetic principles in their unity become generalizing and finalizing. This allows to emphasize the value of aesthetic attitude, aesthetic experience, which is fundamental for musical "attraction of meaning". In the process of musical influence, aesthetic emotions turn into special representations that determine the logical and cognitive presumption of an art object. Aesthetic thinking can be called conceptual thinking at the highest "cloud" level of consciousness. It forces a person to go beyond the boundaries of his own individual psychological structure into the "semantic world" of culture, to expand the value criteria of the socio-historical and individually-personal experience of human life.

\section{SUMMARY}

The article offers a holistic description of musicology discourse, reveals its current methodological factors and interdisciplinary capabilities. The interconnections between musicological and musical language are revealed, the specificity of the artistic nature of music, its main symbolic properties, and special semantic connections with the real world are determined. We study the ability of music to produce its own special meanings; the principles of the musical form as a semiological phenomenon, specialized language sphere, are systematized. At the same time, the role of musicology discourse as the main language of musical understanding and humanitarian metalanguage is justified.

The movement of musicological thought from the external formal organization of musical art, the musical-creative process to the internal "speech" of music is considered; the phenomenon and concept of the internal form are determined. Its significance as a key psychosemantic factor of musical influence is revealed.

The study of form and sense (meaning) in their semiological unity allows us to substantiate the idea of internal form as the central law of the musical logo, to prove the mutual conditionality of form and essence in music, the need for the category of the "inner man". A system of approaches to the phenomenon of musical thinking is being developed, new scientific ideas about the musical "way of thinking"; musical concepts and metalanguage of musicology are being developed. 
An opportunity to position musical concepts as psychological artifacts - the results of material and ideational objectification of a person's relationship to the external and internal conditions of his being, is created. Based on the scientific theories of L. Vygotskyi, E. Etkind and D. Shchedrovitskyi, a musicological concept of the "inner man" is being developed. A systematic model of the internal form is proposed as a form of musical thinking (musical consciousness) based on the categories of sociotypological connections, musical modalities, and “inner man”.

\section{REFERENCES}

1. Аркадьев М. Лингвистическая катастрофа. Антропология абсурда: новый стоицизм. М., 2011. 279 с. URL: http://docplayer.ru/ 26142565-M-arkadev-lingvisticheskaya-katastrofa-moskva-antropologiyaabsurda-novyy-stoicizm.html.

2. Бахтин М. Проблемы поэтики Достоевского. Изд. 3-тье. М.: Художественная литература, 1972. 470 с.

3. Бахтин М. Слово в романе. М. Бахтин. Вопросы литературы и эстетики. Исследования разных лет. М.: Художественная литература, 1775. C. 72-233.

4. Выготский Л.С. Психология искусства. М.: Просвещение, 1968. $280 \mathrm{c}$.

5. Выготский Л. О психологических системах. Л.С. Выготский. Собр. соч. в 6-ти томах. Т.1. М.: Педагогика, 1982. С. 109-131.

6. Гадамер Х.-Г. Семантика и герменевтика. Х.-Г. Гадамер. Актуальность прекрасного: Пер. с нем. М.: Искусство, 1991. С. 60-71.

7. Гессе Г. Игра в бисер. М.: Художественная литература, 1969. $418 \mathrm{c}$.

8. Котляревский И. К вопросу о понятийности музыкального мышления. Музыкальное мышление: сущность, категории, аспекты исследования. К.: Музична Україна. С. 28-34.

9. Мамардашвили М. Эстетика мышления. Беседы. М., 2000. Электронная публикация: Центр гуманитарных технологий. URL: https://gtmarket.ru/laboratory/basis/5061.

10. Мамардашвили М. Необходимость себя. М., 1996.

11. Мечковская Н. Язык и религия: Пособие для студентов гуманитарных вузов. М.: Агенство «ФАИР», 1998. 352 с.

12. Ражников В. Постижение сущности эстетических эмоций и художественных переживаний (авторский словарь и методика его применения). Музыкальное искусство и образование. 4/2013. М. URL: https://cyberleninka.ru/article/n/postizhenie-suschnosti-esteticheskihemotsiy-i-hudozhestvennyh-perezhivaniy-avtorskiy-slovar-i-metodika-egoprimeneniya/viewer. 
13. Руднев В. Словарь культуры ХХ века. М., 1999. 384 с.

14. Вадим Руднев. Новая модель реальности. М., 2016.

15. Самойленко А. Музыковедение и методология гуманитарного знания. Проблема диалога. Одесса: Астропринт, 2002. 244 с.

16. Сошкин Е. К пониманию стихотворения Мандельштама «Дайте Тютчеву стрекозу...» URL: http://textonly.ru/case/?issue=21\& article $=16874$.

17. Шпет Г. Внутренняя форма слова. Этюды и вариации на темы Гумбольта. М., 2006. 216 с.

18. Щедровицкий Д. Внутренний человек. Электронное издание, M., 2016. URL: http://shchedrovitskiy.ru/PDF/978-5-4212-0331-5_ Vnutrenniy_chelovek.pdf.

19. Эко У. Отсутствующая структура. Введение в семиологию. СПб.: ТОО ТК «Петрополис», 1998. - 432 с.

20. Эткинд Е. «Внутренний человек» и внешняя речь. Очерки психопоэтики русской литературы XVIII-XIX вв. М., 1998. 448 с.

Information about the author: Samoilenko A. I., Doctor of Arts, Professor, Vice-rector for Scientific Work, Odessa National A. V. Nezhdanova Academy of Music 63, Novoselskogo str., Odessa, 65023, Ukraine 